\title{
Primary Systemic Treatment and Oncoplastic Breast Surgery - Influences and Principles
}

\author{
Serban-Dan Costa ${ }^{a} \quad H o l m ~ E g g e m a n n^{a} \quad J e n s-U w e ~ B l o h m e r^{b} \quad$ Sherko Kümmel ${ }^{c}$ Bernd Gerber ${ }^{d}$ \\ a Universitäts-Frauenklinik, Otto-von-Guericke-Universität, Magdeburg, \\ ${ }^{b}$ Frauenklinik, Sankt Gertruden Krankenhaus, Berlin, \\ ${ }^{c}$ Klinik für Frauenheilkunde und Geburtshilfe, Universitätsklinik, Essen, \\ dUniversitätsfrauenklinik und Poliklinik am Klinikum Südstadt Rostock, Germany
}

\section{Key Words}

Primary systemic therapy - Breast cancer .

Breast conservation - Oncoplastic surgery

\section{Summary}

Primary or preoperative systemic therapy (PST) has been standard in patients with initially inoperable and inflammatory breast cancer for many years. In stage I and II breast cancer, PST leads to remission in up to $80 \%$ of the cases and up to a $10 \%$ increase in the rate of breast-conserving surgery. Most patients are highly compliant with PST because they quickly notice the efficacy of the therapy. The best surgical results after PST are obtained with oncoplastic procedures, which are done despite a lack of research in this area. After PST, the tumor localization and remission type (centrifugal, centripetal or a combination thereof) play a major role in keeping the rate of reexcisions low. The optimal extent of tissue removal after PST remains controversial, as does the reliability of sentinel node biopsies post PST. These open issues continue to highlight the need for prospective, randomized studies of the indications and techniques used in oncoplastic surgery.

\section{Introduction}

Primary or preoperative systemic therapy (PST) has been standard in patients with initially inoperable and inflammato-

\author{
Schlüsselwörter \\ Primäre systemische Therapie - Brustkrebs . \\ Brusterhaltung · Onkoplastische Chirurgie
}

\section{Zusammenfassung}

Primäre oder präoperative systemische Therapie (PST) gilt als Standardtherapie bei Patientinnen mit inoperablem oder inflammatorischem Mammakarzinom. Beim operablen Mammakarzinom im Stadium I und II führt eine PST in bis zu 80\% der Fälle zu einer Remission, und die Rate an brusterhaltenden Operationen wird durch eine PST um zirka 10\% erhöht. Die Akzeptanz einer PST ist bei Patientinnen aufgrund der selbst wahrnehmbaren Wirksamkeit meist hoch. Die besten operativen Ergebnisse nach einer PST werden durch sogenannte onkoplastische Operationen erzielt, für deren Einsatz jedoch wissenschaftliche Daten fehlen. Nach einer PST sind die Tumorlokalisation und der Tumorremissionstyp (zentrifugal, zentripetal oder eine Kombination der beiden) von großer Bedeutung, um die Rate der Folgeoperationen möglichst niedrig zu halten. Das Ausmaß der Gewebsexzision nach einer PST in den alten oder den neuen Tumorgrenzen und die Zuverlässigkeit der Sentinellymphknotenbiopsie nach PST werden gegenwärtig kontrovers diskutiert. Die offenen Fragen zeigen die Notwendigkeit prospektiver, randomisierter Studien über Indikationen und Techniken onkoplastischer Eingriffe auf.

ry breast cancer for many years. In patients with operable, noninflammatory breast cancer, several well-designed and well-conducted randomized studies have compared PST with adjuvant chemotherapy, resulting in similar survival data

\begin{tabular}{|c|c|c|}
\hline KARGER & (C) 2007 S. Karger GmbH, Freiburg & $\begin{array}{l}\text { Prof. Dr. Dr. Serban-Dan Costa } \\
\text { Universitäts-Frauenklinik, Otto-von-Guericke-Universität }\end{array}$ \\
\hline $\begin{array}{l}\text { Fax +49761 } 4520714 \\
\text { E-mail Information@Karger.de } \\
\text { www.karger.com }\end{array}$ & $\begin{array}{l}\text { Accessible online at: } \\
\text { www.karger.com/brc }\end{array}$ & $\begin{array}{l}\text { Gerhart-Hauptmann-Str. } 35 \\
39108 \text { Magdeburg, Germany } \\
\text { Tel. +49 } 391 \text { 6717-310, Fax -311 } \\
\text { E-mail serban-dan.costa@med.ovgu.de }\end{array}$ \\
\hline
\end{tabular}


[1-6]. In stage I and II breast cancer, PST leads to tumor shrinkage in up to $80 \%$ of the cases, hence improving operability and increasing the rate of breast conservation procedures by $10 \%$ [3, 7-13]. Tumor response, revealing the chemosensitivity of breast cancer, can be monitored easily by palpation or breast ultrasound, and PST can be used as a means for developing innovative, non-cross-resistant chemotherapy regimens [14]. Most patients are highly compliant with PST because they quickly notice the efficacy of the therapy.

However, there are several unresolved issues concerning surgical methods after PST. The main goal of breast-conserving surgery is to remove all cancerous tissue while still retaining as much tumor-free tissue as possible. But the pattern of tumor shrinkage cannot be predicted and tumor remission might occur centrifugally, centripetally, or as a combination of both (fig. 1). Therefore, the extent of tissue excision after PST is controversial: some surgeons advocate excision according to the initial tumor size, while others excise the tissue within the new tumor-free margins. Some of the patients primarily amenable to mastectomy can receive breast conservation after PST. If mastectomy is planned after PST, the most important issue concerning breast reconstruction is the possible necessity of thoracic irradiation because breast implants might be contraindicated. It is still unclear whether a sentinel node biopsy (SNB) can be done after PST with the same sensitivity; the best timing of an SNB also continues to be a controversial topic. Interestingly, in spite of the fact that there are many randomized trials on PST in breast cancer, breast surgery has not been investigated prospectively yet. Since surgery still represents one of the important issues in multimodal breast cancer treatment, we would like to review the available literature in order to derive study concepts aiming to clarify existing dilemmas.

\section{Evaluation of Tumor Remission during and after PST}

Modern chemotherapy regimens given preoperatively lead to tumor response rates of nearly $80 \%$ in breast cancer patients. Partial remission, defined as a volume reduction of more than $50 \%$ is achieved in $40-70 \%$ and pathologic complete remission (pCR) in approximately $20-25 \%$ of the cases $[5,15]$. In subgroups such as patients with HER2-positive tumors, pCR occurs in up to $60 \%$ if trastuzumab is added to chemotherapy [16].

Tumor response can be evaluated clinically by palpation and imaging techniques such as breast ultrasound, mammography, and magnetic resonance imaging (MRI). It has been shown that breast ultrasound predicts better than palpation with a specificity of $90.3 \%$ vs. $61.7 \%$, but a lower sensitivity $(60.5 \%$ vs. $81.6 \%$ ) [15]. All diagnostic means are associated with a high negative predictive value of more than $90 \%$, i.e. they can predict very accurately residual tumor. However, the calculat-

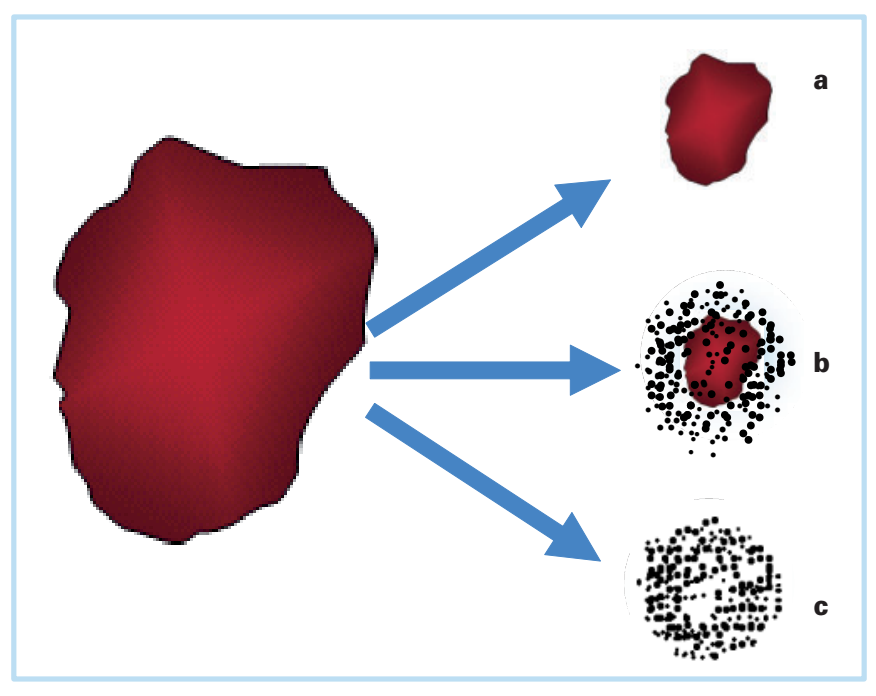

Fig. 1. Tumor remission types after primary systemic therapy in breast cancer patients. a Centripetal tumor remission: Peripheral tumor shrinkage layer by layer, tumor becomes smaller, and no residual tumor cells are detected in the surrounding tissue. b Combination type of tumor remission: The core tumor shrinks leaving diffusely distributed cells in the surrounding tissue. c Centrifugal tumor remission: The core tumor becomes nondetectable mimicking complete response, but the initial tumor area is practically completely interspersed with single tumor cells or tumor cell clusters.

ed positive predictive value for all imaging techniques does not exceed $22-45 \%$. Therefore, patients with pCR after PST cannot be identified precisely enough.

The main reason for the low positive predictive value of all diagnostic means is that tumor shrinkage occurs in different ways. According to our experience, tumors might shrink centripetally ('centripetal tumor remission'), i.e. a big lump becomes smaller when PST destroys the peripheral layers bit by bit (fig. 1). In this case, it is easy to remove the tumor within tumor-free margins because the lump can be identified properly. Another remission type might be named 'centrifugal remission' because the lump disappears, but leaves tumor cell groups or solitary cells in the ductuli diffusely spread within the initial tumor bed. The third type of tumor remission is a combination of those two: the lump becomes smaller, but diffuse tumor cell residues remain in the surrounding tissue of the lump, mainly in the ductuli. The centripetal and the combination type of tumor remission represent a challenge for every breast surgeon because it is difficult to identify the tumor-free margins macroscopically, leading to an increased rate of reoperations.

At present, there are neither data on the proportion of each tumor remission type nor reliable diagnostic procedures to predict the expected remission pattern. Therefore, surgeons still debate the extent of optimum breast tissue removal in breast-conserving procedures. Some surgeons advocate removal of breast tissue according to the initial tumor bed to 

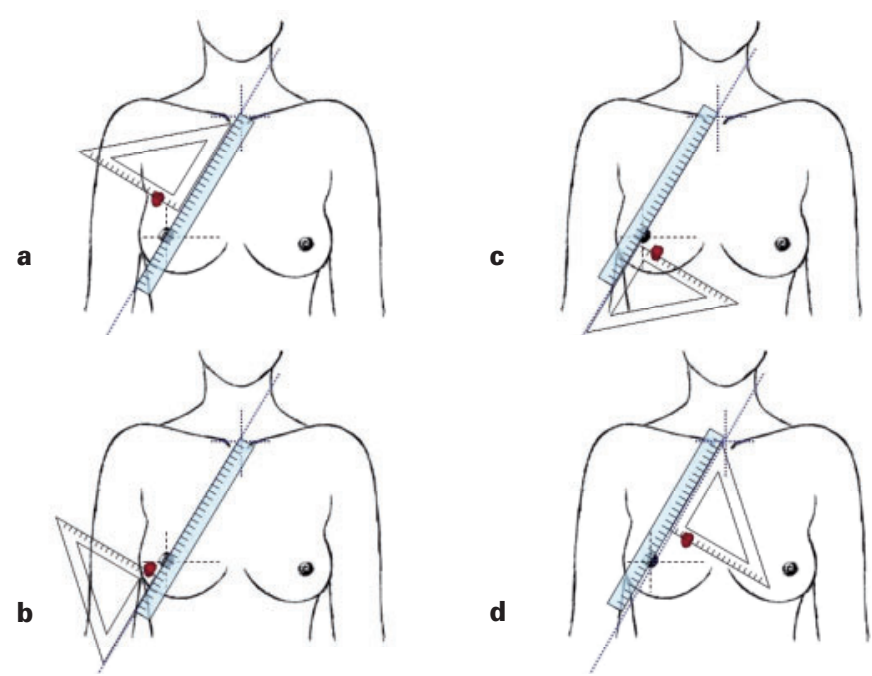

Fig. 2. Localization of a breast tumor using a ruler and a right angle triangle during primary systemic therapy: a upper outer quadrant; $\mathbf{b}$ lower outer quadrant; c lower inner quadrant; $\mathbf{d}$ upper inner quadrant.

avoid reexcisions, while others will remove only the residual lump after PST, chancing possible reexcision procedures and the risks involved in surgery.

\section{Breast-Conserving Surgery after PST}

Several randomized controlled clinical trials comparing PST with the same adjuvant systemic therapy have shown that PST increases the rate of breast-conserving operations by approximately $10 \%[10,11]$. The criteria for breast conservation after PST are basically the same as if adjuvant therapy is planned [12]. Breast conservation is considered feasible by most surgeons if the relationship between tumor size and breast size is favorable and the tumor can be removed with clear margins without compromising the breast shape.

The rate of local relapse after breast-conserving surgery performed after PST is slightly elevated in comparison to primary breast-conserving operations, probably due to the impaired macroscopic identification of diffuse tumor residues around the downsized primary tumor. In the National Surgical Adjuvant Breast and Bowel Project Protocol (NSABP B-18), the rate of local relapse was $10.7 \%$ in the PST group versus $7.6 \%$ in patients receiving adjuvant therapy, but this difference was not statistically significant after a follow-up of 9 years [17]. Besides, the disease-free survival was similar in both groups. Residual carcinoma in situ after PST did not affect patient outcome [18]. Nevertheless, every surgeon should aim to remove the tumor entirely.

In patients with a good response to PST, it might become difficult to localize the tumor in case of partial or complete clinical remission because the tumor cannot be reliably palpated. Since PST is done by medical oncologists in most countries and the surgeons do not see the patient during chemotherapy, the tumor should be localized prior to PST. We have already proposed a simple method (fig. 2) to localize the tumor and determine its size by using a ruler and a right angle triangle [19]. It is also helpful to take photographs of the patient after marking the skin to describe the tumor localization and size before starting PST. If the tumor is not palpable and histological tissue sampling is to be obtained using ultrasound or mammography guidance, a metal clip or coil could be left in situ during the procedure to enable the radiologist to mark the tumor preoperatively [20, 21].

The question on the optimal extent of tissue removal after completion of PST is still unanswered. Whether the tumor should be removed within the 'new margins' (i.e. according to the tumor size after chemotherapy-induced shrinkage) or within the primary, 'old margins' (i.e. according to the initial tumor size at primary diagnosis) remains a matter of debate. In the literature, there is no valid data supporting each of the two strategies. Both treatment modalities are associated with advantages and disadvantages. Thus, removing the tumor within the 'new margins' might lead to an increased rate of reexcisions, as shown in the GEPARDUO trial [22]. Lumpectomy was associated with $24.1 \%$ reexcisions, segmentectomy or quadrantectomies with $19.3 \%$. This difference was statistically not significant, but definition of the surgical procedure was not standardized in this trial and method overlapping cannot be ruled out. Disadvantages of tumor removal within the 'old margins, i.e. the margins prior to PST, might lead to poorer cosmesis due to the more extensive tissue defect, more experimental volume replacement techniques and also more mastectomies. This abolishes one of the aims of PST, namely the increase of the rate of breast conservation.

The standard methods in breast-conserving surgery have been lumpectomy, wide excision or segmental excision with or without overlying skin excision. Recently, breast surgeons have improved cosmetic results of breast-conserving procedures by using intramammary glandular flaps to fill the glandular defect (fig. 3). In patients with macromastia and ptosis, tumor excision can be combined with reduction mammaplasty techniques (we name this procedure tumor-adapted reduction mammaplasty), thus enabling surgeons to remove the tumor with enough surrounding tissue and achieve symmetry by performing contralateral reduction mammaplasty. Depending on the quadrant to be resected, various mammaplasty techniques can be used. Blood supply to the nipple can be achieved by using either an upper (cranial) or lower (caudal) pedicle. Tumors located centrally, underneath the areola, can be treated by the modified Benelli technique [23].

The term 'oncoplastic surgery' has been used to describe breast reconstruction after mastectomy or partial mastectomy $[24,25]$, but also stands for various surgical methods aiming to correct breast volume displacement or redistribution [26]. Oncoplastic surgery ultimately means that the breast surgeon considers oncologic safety as well as esthetic aspects because both can influence survival and quality of life. 


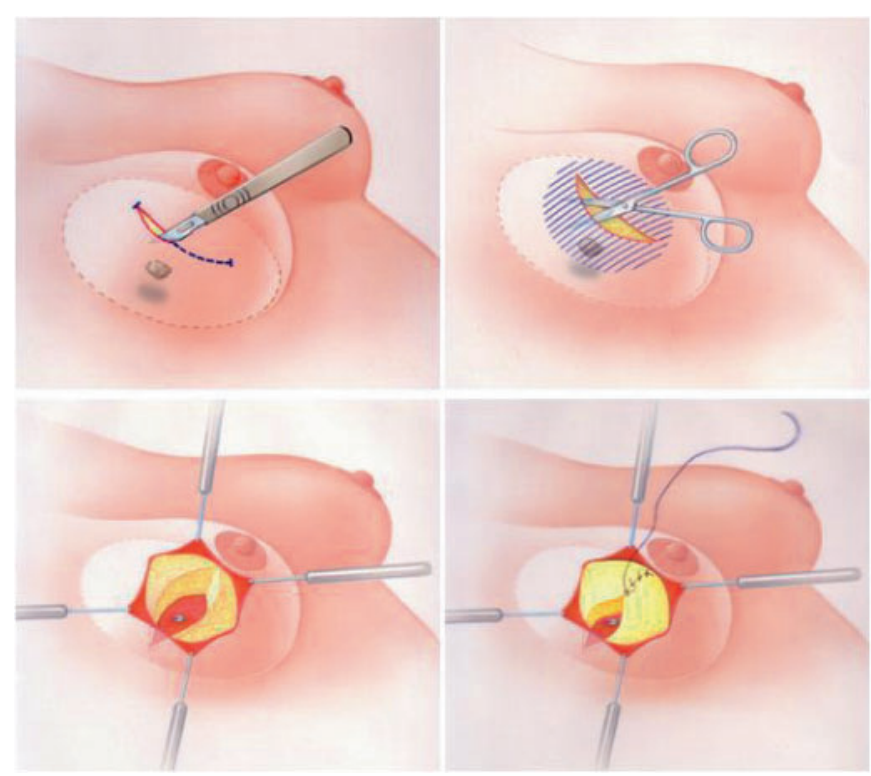

Fig. 3. Principle of segmentectomy and glandular rotation.

Unfortunately, oncoplastic procedures in breast cancer patients have only been reported as case reports and cohort analyses, mostly assessed retrospectively. Prospective, randomized comparisons to standard procedures have not yet been published except for a few papers comparing oncoplastic surgery and standard quadrantectomy or lumpectomy [27, 28]. Therefore, most of the methods described above should still be considered as experimental approaches until randomized prospective studies on oncoplastic breast surgery are done and the results published.

However, a modified radical mastectomy (MRM) is indicated in some cases, especially after repeated resections without clear margins, multicentricity or extended microcalcifications. Otherwise, skin-sparing mastectomy and nipple-sparing mastectomy are also safe oncological procedures for these patients [29].

\section{Surgery of the Axilla after PST}

The axillary lymph node dissection is still the gold standard after PST [30]. Over the past decade it has been the consensus that at least 10 lymph nodes should be removed. Currently, in breast cancer patients with a tumor size less than $2 \mathrm{~cm}$ and a clinically negative axilla, the SNB has been accepted as an alternative to axillary dissection because of its high positive and negative predictive value, as well as its obvious advantage over a full dissection.

Whether SNB can be done after PST is still a matter of debate due to the concern of an increased rate of false-negative sentinel node that has been raised in some clinical studies
[31]. The highest false-negative rate of $20 \%$ occurs in patients with a suspicion of lymph node metastases prior to PST $[31,32]$. Nonetheless, some retrospective analyses have revealed that SNB can be done after PST with the same identification rate and without an increased risk for axillary relapse [33-35].

To date, no randomized studies have been performed with a primary objective of evaluating SNBs after PST. Xing et al. have published a meta-analysis of 21 trials on 1,273 patients with operable breast cancer [36]. All patients had SNB followed by axillary dissection. The identification rate was $72-100 \%$ (mean $90 \%$ ), and the sensitivity was $88 \%$, thus corresponding to data without systemic therapy prior to surgery. We conclude that the sensitivity of an SNB after PST is high enough to warrant its use in this setting.

The learning curve involved when training to identify the sentinel lymph node (SLN) is also valid for the identification after PST. However, a good response to chemotherapy might be associated with a reduced lymphatic drainage towards the axilla in some cases, thus making it more difficult to pinpoint the SLN. At present, SNB cannot be considered as a standard procedure after PST and should be regarded as experimental. In an ongoing randomized, prospective multicenter trial (SENTINA trial) SNB is performed prior to PST in patients with clinically negative axilla and after PST in patients with axillary lymph node metastases prior to PST [37]. The aims of the SENTINA trial are to investigate timing and validity of SNB within neoadjuvant therapeutic concepts in breast cancer.

\section{Conclusion}

Although PST has been standard in patients with initially inoperable and inflammatory breast cancer for many years, it has opened up some areas of controversies that still have not been adequately considered. If it is agreed that tumor removal and quality of life are the main goals of breast cancer therapy, then PST and oncoplastic surgery should factor with priority into the decision of treatment modality.

The several unresolved issues regarding surgery after PST comprise the lack of a uniform method for identifying tumor location before and after PST, the lack of data on the proportion of each tumor remission type (centrifugal, centripetal or a combination) and of reliable diagnostic procedures to predict the expected remission pattern, the question on the optimal extent of tissue removal ('old' vs. 'new margins'), the questions whether SNBs can be reliably done after PST - and if so, at what time and at what sensitivity - and whether SNBs can effectively replace axillary dissection, as well as an obvious lack of prospective, randomized studies on oncoplastic procedures. These issues need to be considered and addressed by the international groups involved in keeping mastology at its forefront. 


\section{References}

1 Fisher B, Bryant J, Wolmark N, Mamounas E, Brown A, Fisher ER, Wickerham DL, Begovic M, DeCillis A, Robidoux A, Margolese RG, Cruz AB Jr, Hoehn JL, Lees AW, Dimitrov NV, Bear HD Effect of preoperative chemotherapy on the outcome of women with operable breast cancer. J Clin Oncol 1998;16:2672-2685.

2 van der Hage JA, van de Velde CJ, Julien JP, Tubiana-Hulin M, Vandervelden C, Duchateau L: Preoperative chemotherapy in primary operable breast cancer: results from the European Organization for Research and Treatment of Cancer Trial 10902. J Clin Oncol 2001;19:4224-4237.

3 Scholl SM, Fourquet A, Asselain B, Pierga JY, Vilcoq JR, Durand JC, Dorval T, Palangie T, Jouve M, Beuzeboc P, Garcio-Giralt E, Salmon RJ, de la Rochefordiere A, Campana F, Pouillart P: Neoadjuvant versus adjuvant chemotherapy in premenopausal patients with tumours considered too large for breast conserving surgery: preliminary results of a randomised trial: S6. Eur J Cancer 1994; 30A:645-652.

$\checkmark 4$ Broët P, Scholl SM, de la Rochefordière A, Fourquet A, Moreau T, De Rycke Y, Asselain B, Pouillart P: Short and long term effects on survival in breast cancer patients treated by primary chemotherapy: an updated analysis of a randomized trial. Breast Cancer Res Treat 1999;58:151-156.

5 Bear HD, Anderson S, Smith RE, Geyer CE, Mamounas EP, Fisher B, Brown AM, Robidoux A Margolese R, Kahlenberg MS, Paik S, Soran A, Wickerham DL, Wolmark N: Sequential preoperative or postoperative docetaxel added to preoperative doxorubicin plus cyclophosphamide for operable breast cancer: National Surgical Adjuvant Breast and Bowel Project Protocol B-27. J Clin Oncol 2006;24:2019-2027.

6 Mauri D, Pavlidis N, Ioannidis JP: Neoadjuvant versus adjuvant systemic treatment in breast cancer: a metaanalysis. J Natl Cancer Inst 2005;97: 188-194.

7 Kuerer HM, Newman LA, Smith TL, Ames FC, Hunt KK, Dhingra K, Theriault RL, Singh G, Binkley SM, Sneige N, Buchholz TA, Ross MI, McNeese MD, Buzdar AU, Hortobagyi GN, Singletary SE: Clinical course of breast cancer patients with complete pathologic primary and axillary lymph node response to doxorubicin-based neoadjuvant chemotherapy. J Clin Oncol 1999;17:460-469.

$>8$ Bonadonna G, Veronesi U, Brambilla C, Ferrari L, Luini A, Greco M, Bartoli C, Coopmans de Yoldi G, Zucali R, Rilke F: Primary chemotherapy to avoid mastectomy in tumors with diameters of three centimeters or more. J Natl Cancer Inst 1990; 82:1539-1545.

9 Makris A, Powles TJ, Ashley SE, Chang J, Hickish T, Tidy VA, Nash AG, Ford HT: A reduction of requirements for mastectomy in a randomized trial of neoadjuvant chemoendocrine therapy in primary breast cancer. Ann Oncol 1998;9:1179-1184.

10 Fisher B, Brown A, Mamounas E, Wieand S, Robidoux A, Margolese RG, Cruz AB Jr, Fisher ER, Wickerham DL, Wolmark N, DeCillis A, Hoehn JL, Lees AW, Dimitrov NV: Effect of preoperative chemotherapy on local-regional disease in women with operable breast cancer: findings from National Surgical Adjuvant Breast and Bowel Project B-18. J Clin Oncol 1997;15:2483-2493.
1 Paepke S, Jacobs VR, Paepke D, Euler U, Blohmer JU, Warm M, Ohlinger R, Fischer T, Kiechle M, Harbeck N: Critical appraisal of primary systemic endocrine therapy in receptor-positive postmenopausal breast cancer: an update. Onkologie 2006;29:210-217.

12 Kaufmann M, Hortobagyi GN, Goldhirsch A, Scholl S, Makris A, Valagussa P, Blohmer JU, Eiermann W, Jackesz R, Jonat W, Lebeau A, Loibl S, Miller W, Seeber S, Semiglazov V, Smith R, Souchon R, Stearns V, Untch M, von Minckwitz G: Recommendations from an international expert panel on the use of neoadjuvant (primary) systemic treatment of operable breast cancer: an update. J Clin Oncol 2006;12:1940-1949.

13 Thomas A, Ohlinger R, Hauschild M, Mustea A, Blohmer JU, Kummel S: Options and limits of surgery after pre-operative chemotherapy in breast cancer. Anticancer Res 2006;26:1677-1682.

14 von Minckwitz G, Blohmer JU, Raab G, Löhr A, Gerber B, Heinrich G, Eidtmann H, Kaufmann M, Hilfrich J, Jackisch C, Zuna I, Costa SD: In vivo chemosensitivity-adapted preoperative chemotherapy in patients with early-stage breast cancer: the GEPARTRIO pilot study. Ann Oncol 2005;16: $56-63$

15 von Minckwitz G, Raab G, Caputo A, Schütte M, Hilfrich J, Blohmer JU, Gerber B, Costa SD, Merkle E, Eidtmann H, Lampe D, Jackisch C, du Bois A, Kaufmann M: Doxorubicin with cyclophosphamide followed by docetaxel every 21 days compared with doxorubicin and docetaxel every 14 days as preoperative treatment in operable breast cancer: the GEPARDUO study of the German Breast Group. J Clin Oncol 2005;23:2676-2685.

16 Buzdar AU, Valero V, Ibrahim NK, Francis D, Broglio KR, Theriault RL, Pusztai L, Green MC, Singletary SE, Hunt KK, Sahin AA, Esteva F, Symmans WF, Ewer MS, Buchholz TA, Hortobagyi GN: Neoadjuvant therapy with paclitaxel followed by 5 -fluorouracil, epirubicin, and cyclophosphamide chemotherapy and concurrent trastuzumab in human epidermal growth factor receptor 2positive operable breast cancer: an update of the initial randomized study population and data of additional patients treated with the same regimen. Clin Cancer Res 2007;13:228-233.

17 Wolmark N, Wang J, Mamounas E, Bryant J, Fisher $\mathrm{B}$ : Preoperative chemotherapy in patients with operable breast cancer: nine-year results from National Surgical Adjuvant Breast and Bowel Project B18. J Natl Cancer Inst Monogr 2001;30:96-102.

18 Mazouni C, Peintinger F, Wan-Kau S, Andre F, Gonzalez-Angulo AM, Symmans WF, Meric-Bernstam F, Valero V, Hortobagyi GN, Pusztai L: Residual ductal carcinoma in situ in patients with complete eradication of invasive breast cancer after neoadjuvant chemotherapy does not adversely affect patient outcome. J Clin Oncol 2007;25: 2650-2655.

19 Costa SD, Eggemann H, Elling D, Bischoff J, Loettge M: Operation nach PST beim operablen Brustkrebs. Onkologie heute 2006;4:29-31.

20 Edeiken BS, Fornage BD, Bedi DG, Singletary SE, Ibrahim NK, Strom EA, Holmes F: US-guided implantation of metallic markers for permanent localization of the tumor bed in patients with breast cancer who undergo preoperative chemotherapy. Radiology 1999;213:895-900.
1 Nadeem R, Chagla LS, Harris O, Desmond S, Thind R, Flavin A, Audisio RA: Tumour localisation with a metal coil before the administration of neo-adjuvant chemotherapy. Breast 2005;14: 403-407.

22 Loibl S, von Minckwitz G, Raab G, Blohmer JU, Dan Costa S, Gerber B, Eidtmann H, Petrich S, Hilfrich J, Jackisch C, du Bois A, Kaufmann M: Surgical procedures after neoadjuvant chemotherapy in operable breast cancer: results of the GEPARDUO trial. Ann Surg Oncol 2006;13: 1434-1442.

23 Gauwerky JHF, Costa SD, Kaufmann M: Technik der Tumorektomie bei zentraler Mammakarzinomlokalisation. Geburtsh Frauenheilk 1996;56:600604.

24 Audretsch W, Rezai M, Kolotas C, Zamboglou N, Schnabel T, Bojar H: Tumor-specific immediate reconstruction in breast cancer patients. Perspect Plast Surg 1998;11:71-106.

25 Anderson BO, Masetti R, Silverstein MJ: Oncoplastic approaches to partial mastectomy: an overview of volume-displacement techniques. Lancet Oncol 2005;6:145-157.

26 Clough KB, Lewis JS, Couturaud B, Fitoussi A, Nos $\mathrm{C}$, Falcou MC: Oncoplastic techniques allow extensive resections for breast-conserving therapy of breast carcinomas. Ann Surg 2003;237:26-34.

27 Giacalone PL, Roger P, Dubon O, El Gareh N, Daurés JP, Laffarque F: Lumpectomy vs oncoplastic surgery for breast-conserving therapy of cancer. A prospective study about 99 patients. Ann Chir 2006;131:256-261.

28 Giacalone PL, Roger P, Dubon O, El Gareh N, Rihaoui S, Taourel P, Daurés JP: Comparative study of the accuracy of breast resection in oncoplastic surgery and quadrantectomy in breast cancer. Ann Surg Oncol 2007;14:605-614.

29 Gerber B, Krause A, Reimer T, Mueller H, Kuechenmeister I, Makovitzky J, Kundt G, Friese $\mathrm{K}$ : Skin-sparing mastectomy with conservation of the nipple-areola complex and autologous reconstruction is an oncologically safe procedure. Ann Surg 2003;238:120-127.

30 Lyman GH, Giuliano AE, Somerfield MR, Benson AB 3rd, Bodurka DC, Burstein HJ, Cochran AJ, Cody HS 3rd, Edge SB, Galper S, Hayman JA, Kim TY, Perkins CL, Podoloff DA, Sivasubramaniam VH, Turner RR, Wahl R, Weaver DL, Wolff AC, Winer EP; American Society of Clinical Oncology: American Society of Clinical Oncology guideline recommendations for sentinel lymph node biopsy in early-stage breast cancer. J Clin Oncol 2005;23: 7703-7720.

31 Jones JL, Zabicki K, Christian RL, Gadd MA, Hughes KS, Lesnikoski BA, Rhei E, Specht MC, Dominguez FJ, Smith BL: A comparison of sentinel node biopsy before and after neoadjuvant chemotherapy: timing is important. Am J Surg 2005;190: 517-520.

32 Nason KS, Anderson BO, Byrd DR, Dunnwald LK, Eary JF, Mankoff DA, Livingston R, Schmidt RA, Jewell KD, Yeung RS, Moe RE: Increased false negative sentinel node biopsy rates after preoperative chemotherapy for invasive breast carcinoma. Cancer 2000;89:2187-2194.

33 Khan A, Sabel MS, Nees A, Diehl KM, Cimmino VM, Kleer CG, Schott AF, Hayes DF, Chang AE, Newman LA: Comprehensive axillary evaluation in neoadjuvant chemotherapy patients with ultrasonography and sentinel lymph node biopsy. Ann Surg Oncol 2005;12:697-704. 
34 Mamounas EP, Brown A, Anderson S, Smith R, Julian T, Miller B, Bear HD, Caldwell CB, Walker AP, Mikkelson WM, Stauffer JS, Robidoux A, Theoret H, Sovan A, Fisher B, Wickerham DL, Wolmark N: Sentinel node biopsy after neoadjuvant chemotherapy in breast cancer: results from National Surgical Adjuvant Breast and Bowel Project Protocol B-27. J Clin Oncol 2005;23:2694-2702.

- 35 Kang SH, Kim SK, Kwon Y, Kang HS, Kang JH, Ro J, Lee ES: Decreased identification rate of sentinel lymph node after neoadjuvant chemotherapy. World J Surg 2004;28:1019-1024.

36 Xing Y, Foy M, Cox DD, Kuerer HM, Hunt KK, Cormier JN: Meta-analysis of sentinel lymph node biopsy after preoperative chemotherapy in patients with breast cancer. Br J Surg 2006;93:539-546.

37 Bauerfeind I, Kuehn T, SENTINA Study Group: The value of sentinel node biopsy after neoadjuvant chemotherapy of primary breast cancer: review and introduction of a prospective study design. Geburtsh Frauenheilk 2007;67:22-27. 